\title{
PENDIDIKAN AGAMA DALAM KULTUR SEKOLAH DEMOKRATIS: Potensi Membumikan Deradikalisasi Agama di Sekolah
}

\author{
Herly Jannet \\ Sekolah Tinggi Agama Kristen Protestan Negeri (STAKPN) Ambon \\ e-mail: bunda_noa@yahoo.com
}

\begin{abstract}
This study aimed in general to determine and describe the religious education in a democratic school culture is one of potential strategies in disseminating religious deradicalization in schools. Applying qualitative naturalistic approach with case study, this study focused the location in Christian High School Urimessing Ambon. The object of this research was the all democratic phenomena found in the process of teaching and learning of Christian education. The results of this study can be described as follows: religious education in a democratic school culture has the potential to disseminate de-radicalization because the learning process optimized the attitude of critical thinking on freedom, independence, and accountability that were assumed to build the belief, attitude and norm of student to: (1) deepen and believe their own religious teachings; (2) commit to transform their religious teacgings in their daily life, both individually and socially; and (3) become the real who got off from violence and anarchy in realizing their objectives.
\end{abstract}

Penelitian ini bertujuan untuk menemukan dan mendeskripsikan Pendidikan Agama dalam kultur sekolah demokratis sebagai salah satu strategi membumikan deradikalisasi agama di sekolah. Metode penelitian yang digunakan adalah kualitatif naturalistik dengan strategi studi kasus dan mengambil tempat penelitian di SMA Kristen Urimessing Ambon. Objek penelitian ini adalah keseluruhan gejala demokratis dalam proses belajar mengajar Pendidikan Agama Kristen. Hasil penelitian dapat dideskripsikan sebagai berikut, Pendidikan Agama dalam kultur sekolah demokratis berpotensi membumikan deradikalisasi, karena dalam proses belajar mengajar mengoptimalkan sikap kebebasan berpikir kritis, kemandirian, dan akuntabilitas sehingga dapat membentuk keyakinan, sikap dan norma peserta didik untuk: (1) mendalami dan meyakini ajaran agamanya sendiri; (2) berkomitmen mentransformasikan ajaran agamanya secara baik dalam kehidupan pribadi maupun sosial bermasyarakat; dan (3) memberi teladan secara konkret tidak terjebak menggunakan kekerasan dan anarkisme dalam mewujudkan keinginan.

Keywords: pendidikan agama, kultur sekolah demokratis, deradikalisasi 


\section{A. Pendahuluan}

Arti penting upaya membumikan deradikalisasi agama tampaknya dilatarbelakangi ketakutan manusia terhadap munculnya gerakan radikal. ${ }^{1}$ Gerakan ini menuntut perubahan berpikir dan bertindak secara mendasar dalam entitas apapun, tidak mengenal agama, batas teritorial negara, ras, suku, dan sekat lainnya. Nilai ketakutan terhadap gerakan radikal ini tampaknya berwujud dalam perasaan terancam dan perasaan tidak nyaman ketika berhadapan dengan gerakan yang dilakukan kelompok radikal. Gerakan radikal diyakini dapat menguncang dan merubah cara berpikir dan bertindak manusia secara mendasar. Bahkan dapat sampai pada tahap menghakimi orang yang tidak sepaham dengan pemikiran kelompok radikal.

Gambaran gerakan radikal yang tampaknya sangat memicu ketakutan dan mengancam manusia adalah gerakan radikal yang tidak jarang menjustifikasi agenda ideologinya dalam tindakan kekerasan bahkan terjebak dalam tindakan terorisme. Adanya berbagai aliran ke-Islaman yang diidentifikasi sebagai gerakan Islam radikal, bahkan dalam tindakan yang lebih vulgar lagi adanya tindakan radikal yang anarkis demi membela atau mengatas-namakan suku, agama bahkan Tuhan telah mengakibatkan munculnya ketidakrukunan dalam kehidupan umat beragama. Hal ini karena adanya cuplikan perilaku umat beragama yang memutarbalikan nilai-nilai ajaran agama ke arah yang menyimpang.

Gerakan radikal dapat ditengarai sebagai gerakan yang amat keras dan ekstrem menuntut perubahan atau merombak secara total cara berpikir dan bertindak manusia secara mendasar. ${ }^{2}$ Gerakan radikal yang amat keras dan ekstrem terus tersebar luas sampai pada pergerakan radikal dengan ditunggangi pergerakan beratas namakan ajaran agama. Pergerakan radikal agama menyusup dengan cara yang sangat cerdik ke arah ajaran agama, paham, akidah, bahkan pengerukan dana terhadap jama'ahnya dan sering kali harta masyarakat luas. Ajaran agama yang pada prinsipnya membawa misi kebaikan, ternyata dalam genggaman gerakan radikal telah memunculkan

${ }^{1}$ Nanang Pamuji M., dkk., "Success Story: Mekanisme Komunitas dalam Penanganan dan Pencegahan Konflik:Studi Kasus di Desa Wayame (Ambon) dan Desa Tangkura (Poso)", Laporan Penelitian bersama Institut Titian Perdamaian, Friedrich Ebert Stiftung dan Panitia 40 tahun FES di Indonesia, 2008, h. 21.

${ }^{2}$ Secara semanrtik radikalisme ialah paham atau aliran yg menginginkan perubahan atau pembaharuan sosial dan politik dng cara kekerasan atau drastis. Kamus Besar Bahasa Indonesia, Kamus versi online, http://kbbi.web.id/radikalisme, diakses pada tanggal 18 Maret 2015. 
agama yang berparas keras, tidak manusiawi, memaksa dan intoleransi. Lebih parah lagi gerakan radikal yang seringkali dibungkus dengan aliran agama, ternyata mewadahi dan mewarnai konflik yang berbau sentimen agama misalnya di Poso, Maluku, 3 dan yang lainnya. Kondisi tersebut semakin memperjelas bahwa ada korelasi antara gerakan radikal di dalam masyarakat dengan doktrin agama.

Maraknya perkembangan gerakan radikal agama yang terjadi saat ini bukan saja meresahkan masyarakat, tetapi telah berhasil membuat jama'ah berani melakukan perubahan terhadap pola pikir dan cara bertindak yang sangat mendasar dalam agama yang diyakini. Pihak pemerintah yang mencermati perkembangan tersebut kemudian terdorong melalui Badan Nasional Penanggulangan Terorisme (BNPT) yang dibentuk pada tahun 2010 menggencarkan salah satu pendekatan dalam soft power-nya yaitu deradikalisasi. Program deradikalisasi pada dasarnya berangkat dari asumsi bahwa terorisme berawal dari radikalisme.

Oleh karena itu dibutuhkan strategi deradikalisasi sebagai upaya yang dianggap cukup efektif untuk memerangi radikalisme. Deradikalisasi pada umumnya bertujuan untuk mengupayakan bagi mereka yang pernah terlibat terorisme maupun bagi simpatisan, sehingga timbul rasa nasionalisme dan mau berpartisipasi dengan baik sebagai warga negara Indonesia, menangkal radikalisasi di kalangan masyarakat yang belum mengalami radikalisasi namun berpotensi untuk mengalami hal tersebut dan menciptakan kesejahteraan sosial dan kesetaraan antar masyarakat.

Jika memperhatikan tujuan deradikalisasi, maka proses deradikalisasi tampaknya bermuatan upaya pengalihan masyarakat yang pernah terlibat aksi terorisme, simpatisan agar meninggalkan atau melupakan aksi terorisme yang berbentuk kekerasan. Kemudian bagi masyarakat yang belum terjangkau aksi terorisme deradikalisasi dapat menumbuhkan dan mengembangkan masyarakat ini menjadi masyarakat yang berbudaya dan beradab, yang mempertahankan dan mencerminkan perilaku dari ajaran agamanya. Baik tujuan pengalihan perilaku terorisme maupun tujuan menumbuhkan dan mengembangkan perilaku masyarakat sesuai ajaran agamanya maka yang harus diutamakan dalam deradikalisasi agama ini adalah proses mengenalkan dan menyadarkan

\footnotetext{
3"Konflik Antar Agama \& Etnis di Poso \& Sampit", http://www.museum.polri.go.id/lantai2_ gakkum_konflik-poso-sampithtml
} 
masyarakat tentang pentingnya menghayati ajaran-ajaran agama yang pantas dan semestinya dijadikan panduan bagi sikap dan perilaku masyarakat sebagai umat beragama.

Upaya untuk mengenalkan, menyadarkan, menghayati dan melakukan ajaran agama sebagai panduan sikap dan perilaku dapat diwujudkan seutuhnya melalui proses Pendidikan Agama di sekolah, di samping proses Pendidikan Agama yang berlangsung dalam keluarga maupun di masyarakat. Walaupun materi atau Pendidikan Agama berbeda sesuai keyakinan masing-masing, tetapi penghayatan dan pemberlakukan ajaran agama pada intinya bertujuan menyatukan agama yang berbeda. Kesatuan agama-agama yang berbeda hanya dapat terwujud dengan melihat dan melakukan peran sosial masyarakat. Peran sosial masyarakat yang bermain dalam kesatuan kepercayaan yang berbeda tentunya diharapkan tidak salah kaprah, tetapi diarahkan pada kesadaran kolektif dalam iklim saling ketergantungan dan bekerjasama.

Dengan demikian Pendidikan Agama di sekolah seharusnya tidak terfokus pada kepentingan teoritis dan dogmatis semata. Tetapi memuat juga tantangan sosial sebagai pengalaman nyata yang nantinya akan dialami peserta didik ketika berada di masyarakat. Pendidikan agama di sekolah bukan hanya mengajarkan norma dan nilai agama tetapi ada praktek membimbing peserta didik bagaimana caranya memperoleh pengetahuan di masyarakat dan mengembangkan secara tepat pengetahuan yang diperoleh tersebut menjadi pandangan hidup yang bermoral dan tidak menyimpang dari ajaran agama yang sebenarnya.

Afif Muhammad menyatakan ada beberapa sebab yang memunculkan radikalisme dalam bidang agama, antara lain: (1) pemahaman yang keliru atau sempit tentang ajaran agama yang dianutnya; (2) ketidakadilan sosial; (3) kemiskinan; (4) dendam politik dengan menjadikan ajaran agama sebagai satu motivasi untuk membenarkan tindakannya, dan (5) kesenjangan sosial atau iri hati atas keberhasilan orang lain. ${ }^{4}$ Kelima penyebab di atas memperlihatkan bahwa Pendidikan Agama seharusnya tidak terbatas pada lingkungan atau konteks religius tetapi mengkontekskan Pendidikan Agama juga pada konteks sosial masyarakat.

\footnotetext{
4Iga Lombok, "Fenomena Gerakan Radikalisme-Fundamental", https://jurnalsrigunting.wordpress .com/tag/radikalisme-terorisme-dan-kejahatan-cyber/, diakses pada tanggal 21 Maret 2015.
} 
Penjelasannya adalah bahwa danya pemahaman yang keliru atau sempit tentang ajaran agama yang dianut diakibatkan karena materi Pendidikan Agama hanya diajarkan untuk mencapai keselamatan jiwa dan bukan untuk menjaga dan membentuk kesejahteraan masyarakat. Ketidakadilan sosial terjadi karena Pendidikan Agama meyakini kesakralan yakni hal-hal yang disisihkan dan terlarang, tetapi tidak dipraktekkan terkait dengan kesatuan moral manusia. Kemiskinan diakibatkan oleh Pendidikan Agama yang hanya didasarkan pada keyakinan religius tetapi tidak bergandengan dengan nilai-nilai emanisipasi pergerakan perubahan di masyarakat sehingga akibatnya jama'ah atau masyarakat mengalami kemiskinan dalam konteks ketidakberdayaan. Dendam politik dengan menjadikan ajaran agama sebagai satu motivasi untuk membenarkan tindakannya, penyebabnya karena harmonisasi Pendidikan Agama dipahami berada dalam institusi religius tanpa harus terbentur dengan padatnya klaim-klaim kebenaran religius lainnya.

Sementara itu penyebab adanya kesenjangan sosial atau iri hati atas keberhasilan orang lain diakibatkan karena Pendidikan Agama hanya mampu menampilkan simbol-simbol keagamaan, Islam bersimbol bulan bintang, Kristen bersimbol salib, Buddha bersimbol dupa, bunga dan dhammacakka (perputaran roda kebenaran), Hindu bersimbol swastika dan Konghucu bersimbol genta, tetapi tidak merujuk peran simbol-simbol tersebut ketika berhadapan dengan sesama manusia, tempat dan peristiwa. Tidak juga ditekankan bahwa simbol keagamaan adalah manusia itu sendiri dan masyarakat secara utuh.

Paparan di atas mencerminkan masih lemahnya Pendidikan Agama dalam memberikan efek penerapan nilai-nilai ajaran agama yang dapat membentuk kesadaran sosial secara kolektif maupun kesadaran bermasyarakat. Pendidikan agama masih lemah dalam menghentikan peran perusak ajaran-ajaran agama semacam radikalisme agama, padahal perusak ajaran agama ini adalah mereka yang beragama. Output Pendidikan Agama justru membentuk keyakinan jama'ah menjadi terkurung dalam praktek ritual dan institusi religius sehingga keyakinan jama'ah mudah tersapu bersih oleh ketertindasan tekanan gerakan radikal agama yang keras dan ekstrem.

Pendidikan agama di sekolah, entah sebab atau justru akibat dari berkutat pada wahyu dan dogma, yang kemudian terjadi adalah sempitnya pemahaman tentang ajaran agama, ketidakadilan sosial, pembenaran ajaran agama untuk 
kepentingan diri sendiri, kesenjangan sosial dan iri hati. Guru Pendidikan Agama jarang mengkomunikasikan materi agama secara interface, artinya membicarakan materi dengan yang diluar dari diri peserta didik. Akibatnya materi pelajaran agama tidak bermakna bagi peserta didik karena peserta didik menyerap materi agama dengan pasif. Hasil Pendidikan Agama sampai saat ini belum memberdayakan peserta didik untuk memaknakan materi pelajaran agama dalam bentuk konstruksi kognitif terhadap objek, pengalaman maupun lingkungannya.

Peserta didik mendalami dogma dan wahyu hanya melalui kitab suci dan hafalan ayat-ayat yang ada dalam kitab suci. Kajian mempelajari tentang Tuhan, dewa dan nabi-nabi lebih berorientasi pada mempelajari sejarah hidup dan mujizat yang dibuat. Tetapi memaknai dan mengkonstruksi spiritualisasi Tuhan, dewa dan nabi-nabi dengan konteks hidup peserta didik tidak dioptimal. Peserta didik dikulturkan dalam proses belajar mengajar (PBM) Pendidikan Agama dengan nilai-nilai kesakralan yang sama sekali tidak dibenturkan dengan konsekuensi sosial praktek-praktek masyarakat di luar sana.

Akibatnya tidak salah jika radikalisme agama dengan mudah memporakporandakan cara berpikir dan bertindak yang sangat mendasar dari umat beragama. Tidak salah juga jika umat beragama menjadi miskin, dalam arti tidak berdaya karena umat beragama "buta" dalam ekonomi politik yang berdampak langsung pada kenyataan bahwa manusia secara sederhana harus makan, minum, memiliki sandang dan papan sebelum melibatkan diri dalam aktivitas ilmu, politik, agama dan lainnya.

Prioritas Pendidikan Agama sudah saatnya berproses dalam kultur demokratis sehingga peserta didik kelak menjadi manusia yang ampuh memerangi kontradiksi ajaran agama yang berseberangan dan menjadi aplisikator yang bermoral keagamaan. Pendidikan agama dalam kultur demokratis mempolakan proses belajar mengajar (PBM) yang terhubung dengan kegiatan inisiatif indepeden seperti, pengalaman nyata di lingkungan sosial yang setara dengan perkembangan peserta didik, sehingga ada wawasan ke dalam stuktur psikologis yang mempengaruhi pencapaian hasil belajar. ${ }^{5}$ Proses belajar mengajar lebih diarahkan untuk peserta didik dimanusiakan, memberikan layanan yang

5J. Dewey, "Famous Declaration Concerning Education", pertama kali dipublikasikan dalam The School Journal, Vol. LIV, No. 3, 77-80, 1987, h. 77. 
kondusif bagi pertumbuhan dan perkembangan optimal peserta didik, dan belajar sambil bekerja sehingga peserta didik mampu berpikir kritis.

Kultur demokrasi dianggap tepat untuk mendukung Pendidikan Agama karena ada tiga hal wajib yang perlu dilakukan dalam pelaksanaan Pendidikan Agama yaitu: (1) kepercayaan atau keyakinan adalah indikator yang dihasilkan melalui komunikasi yang membahas penyatuan dogma atau wahyu dengan kenyataan empiris. Bahwa Pendidikan Agama adalah bagian dari hidup maka PBM seharusnya membenturkan keyakinan dengan konsekuensi kehidupan bermasyarakat sehingga berpotensi memberdayakan peserta didik; (2) Itikad baik sebagai bentuk perilaku beragama melibatkan interaksi sosial di mana dalam berinteraksi keyakinan terhadap wahyu atau dogma menjadi tetap menjadi kontrol sosial dalam masyarakat yang beragama, dan (3) norma atau nilai agama yang berkembang dalam PBM sesungguhnya telah memberi individu pengalaman untuk berelasi secara kritis dimasyarakat tanpa menimbulkan kekacauan.

Jika Pendidikan Agama dalam kultur sekolah demokratis dioptimalkan secara tepat maka dapat berpotensi membumikan deradikalisasi agama di sekolah karena: (1) Pendidikan Agama berfokus pada makna tindakan demokratis yang memiliki pola hubungan yang harmonis dan terbangunnya kepercayaan; (2) makna keyakinan yang dibentuk dalam PBM secara demokratis dimainkan dalam kebebasan yang bertumpu pada interaksi dan kerja sama, berdasarkan sikap saling menghormati, dan (3) berbagai perubahan dalam masyarakat mampu disikapi dengan perangkat moral. Dengan konsep di atas kajian ini akan memfokuskan perhatian pada upaya pendidikan demokratis yang diterapkan di SMA Kristen Urimessing Ambon serta Pendidikan Agama dalam budaya demokratis.

\section{B. Membangun Kultur Demokratis di Sekolah}

Beberapa elemen penting dalam kultur dapat disebut antara lain, norma, nilai-nilai, keyakinan, tradisi, ritual, upacara dan mitos yang diterjemahkan oleh sekelompok orang. Simbol-simbol ini dapat dikomunikasikan dalam bentuk: (1) sengaja, (2) secara khusus kepada seseorang, (3) secara sosial sebagai kode yang ditetapkan, dan (4) tanpa sadar. ${ }^{6}$

${ }^{6}$ C. Feertz, The Interpretation of Cultures, (New York: Basic Books, 1973), h. 470.

Walisongo, Volume 23, Nomor 1, Mei 2015 
Kultur tidak diwariskan secara genetik, dan tidak bisa ada dengan sendirinya, tetapi selalu bersama dengan anggota masyarakat.7 Demikian juga dengan kultur di sekolah yang dibentuk dalam perjalanan panjang sejarah sekolah sehingga menjadi jiwa dan kekuatan sekolah yang memungkinkan sekolah dapat tumbuh berkembang dan melakukan adaptasi dengan berbagai lingkungan yang ada. ${ }^{8}$ Dengan demikian kultur sekolah dapat mengacu pada keyakinan, norma dan sikap yang terus bertumbuh dalam keyakinan dan pengakuan warga sekolah.

Konsep demokrasi yang ditumbuhkan menjadi kultur dalam PBM Pendidikan Agama yaitu jiwa demokrasi yang menjunjung tinggi kepentingan hidup bersama, jiwa kerakyatan dan keadilan sosial, merupakan pencerminan luluhnya rasa aku, dan rasa kita adalah jiwa kekeluargaan. ${ }^{9}$ Orientasi demokrasi ini lebih mendalami demokrasi sebagai sendi kebutuhan kodrat manusia untuk memperoleh kemerdekaan secara wajar.

Demokrasi yang ditularkan berfokus pada apa yang disebut conscious social reproduction, karena demokrasi hanya akan bertahan jika kehidupan melingkupi bidang sosial. Conscious social reproduction artinya kesadaran mereproduksi dengan cara non-represif, tidak boleh membatasi cara hidup dengan pertimbangan rasional yang berbeda. Namun demikian, sebaliknya yang harus dilakukan adalah mengembangkan jenis karakter dan jenis kecerdasan yang memungkinkan orang untuk memilih secara rasional cara-cara hidup yang berbeda. ${ }^{10}$ Pendidikan sebagai conscious social reproduction bertujuan secara sosial bertujuan untuk menumbuhkan kemampuan yang mencerminkan tindakan pada sendiri dan dan tindakan orang lain.

Nilai demokrasi yang dikembangkan conscious social reproduction antara lain: (1) Mengembangkan keyakinan untuk mampu mengambil bagian di dalam hidup masyarakat. (2) Menjadi terbuka, toleran dan bertanggung jawab dalam melatih hak dan tanggung-jawab. (3) Mengumpamakan peran, hak dan tanggung-jawab yang pada umumnya berhubungan dengan kewarganegaraan di dalam sistem demokratis. (4) Mengkonstruksi hak sosial dan ekonomi.

\footnotetext{
7E.T. Hall, Beyond culture, (New York: Anchor Books/Doubleday, 1976), h. 16.

8Zamroni. Pendidikan Demokrasi pada Masyarakat Cultural, (Yogyakarta: Gavin Kalam Utama, 2011), h. 149.

${ }^{9}$ K.H. Dewantara, Pendidikan, (Yogyakarta: Majelis Luhur Persatuan Taman Peserta Didik, 1977), h. 7.

${ }^{10}$ A. Gutmann, A. Democratic Education with a New Preface and Epilogue, (New Jersey: Princeton University Press. 2006), h. 404.
} 
(5) Membangun kapasitas bertindak yang saling berhubungan, mengevaluasi dan memproses hasil pengetahuan yang diterima di masyarakat secara kritis dengan tetap mempertahankan keyakinan mendasar

Selanjutnya, Pendidikan Agama pada umumnya diprovokasi dengan pertanyaan yang menantang tentang makna hidup, keyakinan tentang Tuhan, diri dan sifat realitas, masalah hak dan apa artinya menjadi manusia. Pertanyaanpertanyaan yang memuat makna dan tujuan dari Pendidikan Agama antara lain: (1) mengembangkan pengetahuan dan pemahaman peserta didik tentang agamanya sendiri, agama-agama lain, tradisi agama lain, dan pandangan dunia yang menawarkan jawaban untuk menjawab pertanyaan-pertanyaan di atas. (2) menawarkan kesempatan bagi peserta didik untuk mengembangkan refleksi pribadi dan spiritual. (3) meningkatkan kesadaran dan pemahaman peserta didik tentang agama, keyakinan, ajaran, praktek dan bentuk ekspresi, serta pengaruh agama pada diri sendiri, keluarga, masyarakat dan budaya. (4) mendorong peserta didik untuk belajar berbagai agama, keyakinan, nilai-nilai dan tradisi, sambil menjelajahi keyakinan dengan pertanyaan yang dibuat dan dimaknakan oleh peserta didik sendiri, dan (5) menantang peserta didik untuk merenungkan, mempertimbangkan, menganalisis, menafsirkan dan mengevaluasi masalah kebenaran, keyakinan, iman dan etika untuk berkomunikasi dengan tanggap dan kritis. Inti Pendidikan Agama membawa pengetahuan dan pemahaman agama dalam lingkup pikiran manusia dan tindakan ketimbang hanya meyakini ajaran agama. ${ }^{11}$

Bila menganalisis konsep Pendidikan Agama di atas maka ada elemen dasar yang tidak berperan dengan baik dalam Pendidikan Agama yaitu peran Pendidikan Agama melalui komunikasi dan dialog antar peserta didik untuk pengembangan pengetahuan, kecakapan, dan kepribadian peserta didik. Komunikasi dan dialog antar peserta didik isinya berupa perenungan mengenai masalah-masalah etis yang dapat terjadi di masyarakat manakala peserta didik diminta untuk mengevaluasi, mengambil atau mempertahankan suatu pendapat tentang hal-hal yang melibatkan pertimbangan-pertimbangan etis dan agamis yakni isu-isu mengenai baik-buruk, benar-salah.

Upaya meningkatkan kecakapan partisipasi peserta didik melalui komunikasi dan dialog membutuhkan PBM yang berlangsung secara demokratis. Penelitian yang dilakukan oleh Fathurrohman Wahid, menunjukkan bahwa pembelajaran demokratis memudahkan guru dalam menyampaikan materi karena

${ }^{11}$ H.P.Edwards, Religius Education in a Pluralist Society, (London-Portland: Wobum Press, 1999), h. 18. 
peserta didik berperan aktif, adanya kesesuaian antara teori dengan objek penelitian, dibuktikan dengan metode yang diterapkan yaitu metode kerja kelompok, diskusi dan tanya jawab. Meskipun penerapan pembelajaran demokratis belum memuaskan namun kegiatan pembelajaran di kelas bisa berjalan dengan efektif. Hal ini terlihat dengan indikator pembelajaran demokratis akan keterbukaan saluran ide dan gagasan, menyampaikan kritik sebagai analisis dalam proses penyampaian evaluasi terhadap ide-ide, memperhatikan kepedulian terhadap orang lain dan harga diri. ${ }^{12}$

Samuel Awuah-Nyamekye dalam penelitiannya Religious Education in a Democratic State: the Case of Ghana. Hasil penelitian yang dilakukan pada 2010 itu menunjukkan Pendidikan Agama tidak dapat disajikan untuk mengubah iman murid untuk agama tertentu, tetapi untuk menyajikan masing-masing agama dengan objeknya sendiri dan peserta didik membuat keputusannya sendiri. Pendidikan Agama di sekolah umum untuk negara demokratis seperti Ghana adalah untuk mendidik peserta didik tentang berbagai tradisi agama, bukan untuk mengindoktrinasi peserta didik ke dalam tradisi apapun. Materi Pendidikan Agama diajarkan secara objektif dan netral, serta mendidik peserta didik tentang sejarah dan warisan budaya mereka sendiri dan orang lain. Ini berarti bahwa guru yang tidak akademis dan profesional yang kompeten seharusnya tidak diperbolehkan untuk menangani Pendidikan Agama di negara demokratis seperti Ghana. Tujuan nyata dari Pendidikan Agama adalah untuk mempersiapkan peserta didik untuk mengembangkan mental, fisik, moral dan sosial sehingga peserta didik dapat memahami lingkungan mereka dan mereka dapat berfungsi sebagai anggota masyarakat yang berguna. Ini juga akan membekali peserta didik untuk bersaing dalam realitas globalisasi. Dukungan pemerintah di bidang pendidikan yaitu harus memastikan bahwa semua faktor yang menghambat Pengajaran Pendidikan Agama di sekolah-sekolah umum di Ghana di semua tingkat akan dihapus dari waktu ke waktu, melalui revisi silabus Pendidikan Agama untuk mencerminkan realitas di lapangan. ${ }^{13}$

Penelitian pembelajaran demokratis dalam Pendidikan Agama di atas walaupun sudah menjadikan nilai-nilai demokrasi sebagai pusat Pendidikan Agama tetapi nilai-nilai demokrasi tersebut hanya difungsikan melalui metode

\footnotetext{
${ }^{12}$ Fathurrohman Wahid, "Pembelajaran Demokratis pada Bidang Studi Pendidikan Agama Islam di SMAN 29 Jakarta”, Skripsi, (Jakarta: UIN Syarif Hidayatullah, 2010).

${ }^{13}$ S.A-Nyamekye, Religious Education in a Democratic State: The Case of Ghana, (Departement of Religion \& Human Values, 2010), h. 3.
} 
belajar. Bukan diyakini dalam sikap dan tercermin menjadi nilai atau norma bagi peserta didik. Kultur demokratis dalam PBM Pendidikan Agama bukanlah seperangkat aturan yang mengatur perilaku juga tidak bekerja sebagai proses rasional secara sadar. Namun, sebagai kerangka di mana guru dan peserta didik berinteraksi masuk dan keluar sampai pada tingkat tidak terpikirkan. Interaksi perilaku atau tindakan demokratis ini tetap dipelihara dan terus ditingkatkan mencapai tingkat kepatuhan dan akibatnya interaksi perilaku atau tindakan demokratis ini menjadi sifat batin atau watak demokratis yang mempengaruhi segenap pikiran dan tingkah laku manusia beragama.

\section{Upaya Membangun Pendidikan Demokratis}

Terdapat berbagai upaya yang bisa dilakukan dalam membangun pendidikan demokratis sebagaimana yang telah diterapkan di SMA Kristen Urimessing Ambon, di antaranya adalah:

\section{Mengembangkan Pengetahuan dan Pemahaman Peserta Didik tentang Agamanya Sendiri, Tradisi dan Agama Lain, dan Pandangan Dunia}

Siswa terbagi dalam lima kelompok setiap kelompok mengkaji manusia dewasa dalam iman menurut agama yang berbeda, Islam, Kristen Protestan, Kristen Khatolik, Buddha, dan Hindu. Siswa kemudian menganalisis perbedaan serta membentuk konsep dari kajian agama yang berbeda-beda dan menggeneralisasi kesamaan yang ditemukan. Tujuan mencari perbedaan adalah agar siswa mengetahui dan memahami makna yang ada dalam tiap-tiap mengenai cara bertumbuh dalam iman tiap agama. Metode yang digunakan diskusi. Sikap siswa dalam berdiskusi, siswa sendiri membagi anggota kelompok yang mencari persamaan dan mencari yang berbeda. Temuan siswa dalam bagan berikut:

Tabel 1.

Perbedaan Memaknai Iman Masing-masing Agama

\begin{tabular}{|c|c|c|}
\hline No. & Kelompok Agama & Pengertian Iman dan Cara Beriman \\
\hline 1 & Agama Islam & 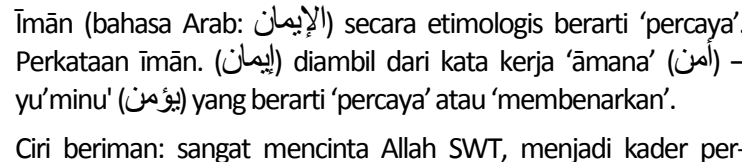 \\
\hline
\end{tabular}

Walisongo, Volume 23, Nomor 1, Mei 2015 


\begin{tabular}{|c|c|c|}
\hline & & $\begin{array}{l}\text { juangan Islam, selalu komitmen dalam syahadatnya, tiap pekerja- } \\
\text { an selalu didasari ilmu, mentaati aturan, hidup berjama'ah, dan } \\
\text { senantiasa bersyukur. }\end{array}$ \\
\hline 2 & Agama Buddha & $\begin{array}{l}\text { Agama Buddha tidak mengenal iman dan tidak pernah diajarkan } \\
\text { untuk 'mengimani' sesuatu. Agama Buddha mengajarkan untuk } \\
\text { mempelajari serta membuktikan kebenaran Buddha Dharma. } \\
\text { Kalau seseorang setelah mempelajari dan merasakan manfaat } \\
\text { pelaksanaan dharma, maka dalam dirinya akan tumbuh ke- } \\
\text { yakinan (saddha) yang tentunya berbeda dengan iman yang tidak } \\
\text { harus melewati pembuktian. Oleh karena itu, timbulnya keyakin- } \\
\text { an (saddha) bukan hanya karena akal saja, melainkan dari peng- } \\
\text { alaman melaksanakan Buddha Dharma juga. Buddha sebagai } \\
\text { guru yang berwenang mengajarkan kebenaran, percaya me- } \\
\text { nyerahkan diri kepada dharma atau ajaran Buddha, sebagai yang } \\
\text { membawanya kepada kelepasan, dan percaya setelah menyerah- } \\
\text { kan diri kepada jemaat sebagai jalan yang dilaluinya. }\end{array}$ \\
\hline 3 & Agama Hindu & $\begin{array}{l}\text { Sembahyang intinya adalah iman atau percaya sehingga semua } \\
\text { tingkah laku atau perbuatan, pikiran dan ucapan sebagai per- } \\
\text { wujudan dalam bentuk "bakti" hakikatnya sumber pada unsur iman } \\
\text { (sradha). Suci lahiriah, suci batiniah, dan suci laksana (hidup) }\end{array}$ \\
\hline 4 & $\begin{array}{l}\text { Agama Kristen } \\
\text { Khatolik }\end{array}$ & $\begin{array}{l}\text { Apostolik - Iman kepada Yesus Kristus mewarisi iman para rasul. } \\
\text { Jadi isi iman tidak menyimpang dari ajaran Yesus sebagaimana } \\
\text { diteruskan oleh ke-12 rasul. iman dengan perbuatan bukan hanya } \\
\text { dengan kata-kata atau sekedar keyakinan dalam hati. Iman } \\
\text { didasarkan pada pernyataan: iman tanpa disertai perbuatan pada } \\
\text { hakikatnya adalah mati (Yak 2:17) }\end{array}$ \\
\hline 5 & $\begin{array}{l}\text { Agama Kristen } \\
\text { Protestan }\end{array}$ & 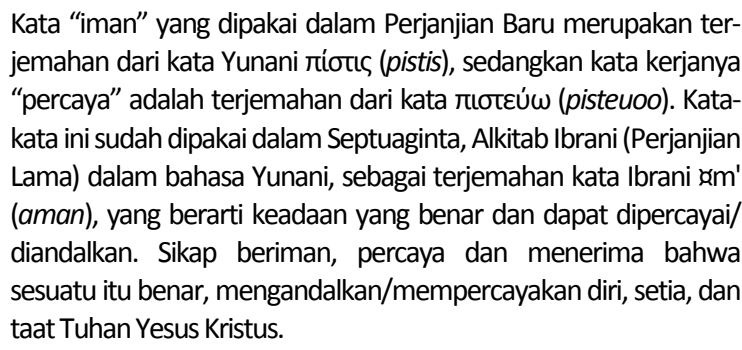 \\
\hline
\end{tabular}

Hasil penyampaian diskusi kelompok menunjukkan, (1) siswa meyakini ada perbedaan pemahaman beriman, (2) sikap melakoni iman juga berbeda, (3) tetapi nilai dan tujuan dari pertumbuhan iman tampaknya sama; beriman percaya kepada Tuhan dan melakukan perintah Tuhan juga berbuat baik bagi sesama. 


\section{Menawarkan Kesempatan bagi Siswa untuk Mengembangkan Refleksi Pribadi dan Spiritual}

Beberapa cuplikan refleksi pribadi dan spiritual siswa yaitu: (1) beriman adalah sikap-sikap percaya dan taat kepada Tuhan. Dalam sikap beriman tiap agama berbeda, tetapi cara beriman harus dihormati karena keyakinan untuk memperoleh keselamatan dari Tuhan juga berbeda, (2) iman berarti mengakui bahwa setiap agama punya cara berdoa yang berdoa dengan iman mereka yang berbeda, tetapi doa yang dinaikkan tujuannya hanya kepada Tuhan untuk keselamatan semua umat beragama bukan hanya satu agama saja yang umatnya menerima keselamatan dari Tuhan, (3) beriman juga berarti berbuat baik kepada sesama manusia termasuk kepada umat beragama yang tidak seiman. Setiap agama pasti mengajarkan umatnya untuk berbuat bagi orang lain, karena itu adalah bagian dari perbuatan orang iman.

Beberapa cuplikan refleksi pribadi dan spiritual siswa di atas menunjukan, jika PBM memberi ruang kebebasan bagi siswa merefleksi secara pribadi dan spiritual siswa terhadap materi pelajaran agama akan nampak berbagai komentar yang diyakini peserta dituangkan. Dalam refleksi pribadi akan ditunjuk identitas pribadi siswa menanggapi ajaran-ajaran agama lain.

\section{Meningkatkan Kesadaran dan Pemahaman Siswa tentang Keyakinan, Sikap dan Nilai Materi Pelajaran Agama pada Diri Sendiri, Keluarga, Masyarakarat dan Budaya}

Pada tahap pembelajaran ini, siswa dibagikan dalam kelompok dengan kasus-kasus yang berbeda. Kasus dalam keluarga, masyarakat dan budaya khusus budaya toleransi umat beragama. Setiap kasus diselesaikan dengan tahapan, memaparkan fakta-fakta berdasarkan kasus, kemudian mengkonsep fakta-fakta tersebut dan disusun dalam bentuk berita yang akan dimuat di koran, berita di internet, berita di televise, radio dan status di facebook. Dalam konsep berita tersebut peserta didik sekaligus sudah mengusulkan solusi atau pemacahan terhadap kasus.

Salah satu contoh yang dibuat peserta didik tentang tawuran. Menulis status di facebook "tawuran lagi, tawuran lagi, bosan teman-teman. Daripada tawuran lebih baik ngumpulin uang per orang Rp. 2000,- kita makan samasama di warteg, ada indo mie rebus, indo mie goreng, nasi goreng murah meriah, es teh, es buah daripada tawuran nanti ditangkap polisi, belum lagi diskros dari sekolah". Cara peserta didik menyampaikan kalimat-kalimat di 
atas menunjukan bahwa peserta didik pada prinsipnya tahu betul mana sikap dan perilaku yang benar-salah atau baik-buruk. Peserta didik meyakini bahwa ajaran agama mengajarkan mana sikap dan perilaku yang salah dan benar. Apa upahnya kalau melakukan perbuatan yang baik dan apa upahnya kalau melakukan perbuatan yang salah. Guru seharusnya dapat menciptakan PBM yang menumbuhkan semangat partisipasi peserta didik secara aktif dan bertanggung jawab, dan bertindak secara cerdas dalam menyikapi kasus-kasus dalam masyarakat.

\section{Mendorong Siswa untuk Belajar Berbagai Agama, Keyakinan, Nilai-nilai dan Tradisi, sambil Menjelajahi Keyakinan dengan Pertanyaan yang Dibuat dan Dimaknakan oleh Siswa Sendiri}

Setelah mempelajari perbedaan ajaran iman dan berperilaku beriman dari setiap agama siswa kemudian ditugaskan secara pribadi dimana untuk merumuskan pertanyaan terhadap makna pertumbuhan iman dalam setiap agama. Pertanyaan yang dirumuskan siswa antara lain, apa defenisi iman menurut agama masing-masing, sikap apa yang harus dilakukan sebagai bentuk cara beriman dari setiap agama, dan apa yang harus dibuat supaya beriman dengan taat. Salah seorang peserta didik menuliskan pertanyaan dan menjawab demikian, Bagi Budhha: beriman adalah melakukan dengan taat semua ajaran Budhha. Supaya dapat beriman dengan sikap yang taat melakukan ajaran Budhha sampai menemukan kebenaran maka harus luangkan waktu untuk meditasi secara rutin, sehingga ada ketenangan untuk merenungkan berbuat baik dan benar bagi sesama manusia.

Proses belajar mengajar dengan membiasakan siswa membuat pertanyaan dan menjawab pertanyaan sendiri adalah bentuk PBM demokratis yang mengajarkan siswa belajar mandiri. Guru hanya aktif memberikan arahan dan informasi jika diperlukan oleh siswa. Guru sekaligus memberikan siswa berkembang dengan potensi dan kemampuannya sendiri.

\section{Menantang Siswa untuk Merenungkan, Mempertimbangkan, Menganalisis, Menafsirkan dan Mengevaluasi Masalah Kebenaran, Keyakinan, Iman dan Etika untuk Berkomunikasi dengan Tanggap dan Kritis}

Tahap ini adalah tahap evaluasi yang dilakukan oleh siswa sendiri terhadap penguasaan materi pelajaran. Dalam tahap merenungkan peserta didik me- 
nuliskan sesuai konsep pikir manusia dewasa dalam iman bertumbuh; tahap mempertimbangkan siswa mengemukakan tantangan apa saja yang dapat dihadapi saat iman mengalami pertumbuhan; tahap menganalisis setiap tantangan peserta didik diharapkan dapat memilah tantangan dari dalam diri maupun dari luar diri: tahap menafsirkan peserta didik memberikan pendapat tentang sikap untuk menyikapi tantangan yang sudah dipaparkan. Dalam nilai keyakinan beriman apa saja yang diyakini siswa menguraikan sesuai keyakinan siswa masing-masing; dalam etika bermasyarakat apa sikap siswa sebagai orang beriman juga dituliskan masing-masing.

Dalam format evaluasi seperti yang dipaparkan di atas, diperlihatkan bahwa evaluasi dalam PBM agama bukan untuk mengevaluasi kemampuan siswa mengahafal defenisi tentang dogma, wahyu atau simbol-simbol keagamaan; bukan juga evaluasi dalam bentuk memilih jawaban yang sudah tersedia. Tetapi evaluasi dalam PBM Pendidikan Agama adalah evaluasi dalam bentuk refleksi pribadi terhadap pengetahuan atau materi ajaran agama yang sudah diterima selama PBM berlangsung.

\section{Menuju Deradikalisasi: Pendidikan Agama dalam Kultur Sekolah yang Demokratis}

Fakta bahwa gerakan radikalisme adalah gerakan yang mengancam dan menekan keyakinan beragama di masyarakat, membuktikan baik pelaku radikalisme maupun masyarakat masih memaknai ajaran agama hanya sebagai alat atau perangkat saluran pipa teoritis dari otak yang satu ke otak yang lain, atau seperti kawat listrik yang mengalirkan arus listrik dari posisi ke posisi. Padahal ajaran agama sama sekali tidak ada pipa, tidak ada kawat penghubung otak ke otak manusia lain. Ajaran agama merupakan suatu hal lahiriah yang terlepas dan sama sekali tidak bermakna sampai ada yang menafsirkan makna ajaran agama ke dalam serangkaian tindakan.

Pertanyaan "apa yang sedang terjadi" adalah hal nyata bagi gerakan radikalisme. Menyikapi apa yang sedang terjadi dengan gerakan radikalisme tidak bisa hanya dengan gagasan, konsep, atau perasaan bahwa gerakan radikalisme bertentangan dengan ajaran agama. Tetapi harus dipahami dan disikapi dengan fakta riil di luar pikiran manusia. Pola perilaku, cara berpikir sampai pada pola internalisasi dari nilai-nilai ajaran agama yang dipraktikkan gerakan radikalisme harus dianalisis sebagai satu kesatuan yang utuh dari 
berbagai bagian yang saling berinteraksi. Analisis yang utuh terhadap gerakan radikalisme tentu akan menimbulkan ketegangan yang dapat sampai pada kesimpulan bahwa gerakan radikalisme adalah gerakan yang bertentangan dengan ajaran agama.

Pendidikan agama di sekolah yang berfungsi bukan sebagai saluran pipa untuk menyalurkan ajaran agama harus bergerak mendekati peserta didik agar hidup mempertahankan agama serta ajaran agama yang diyakininya. Pendekatan dalam Pendidikan Agama tentunya lebih bermakna untuk menyikapi gerakan radikalisme dengan tetap menjaga kelestarian dan kesejahteraan masyarakat. Oleh karena itu Pendidikan Agama di sekolah dalam kultur yang demokratis dianggap dapat memberikan perintah-perintah yang bersifat demokratis menyikapi gerakan radikalisme.

Perintah dalam Pendidikan Agama dalam kultur sekolah yang demokratis menyikapi gerakan radikalisme yaitu: (1) perhadapkan berbagai kondisi dan situasi gerakan radikalisme yang mempengaruhi pola pikir dan rasa peserta didik; (2) perlihatkan bukti bahwa gerakan radikalisme bertentang dengan ajaran agama; (3) biarkan peserta didik memilih dan menentukan cara yang tepat berdasarkan ajaran agama menyikapi setiap gerakan radikalisme, dan (4) debatkan dan komandokan gerakan nyata dari ajaran agama yang benar dan bermoral dikalangan peserta didik sehingga peserta didik mampu dan bertekad mempertahankan nilai-nilai, norma-norma, dari ajaran agama yang menentang gerakan radikalisme.

\section{E. Kesimpulan}

Upaya pendidikan demokratis di SMA Kristen Urimessing Ambon dilaksanakan dengan model refleksi subjektivitas dan inter-subjektivitas. Dengan model itu siswa belajar untuk memahami agama lain, tradisi dalam agama lain, nilai-nilai keimanan, dampak keimanan dalam kehidupan diri, keluarga dan masyarakat serta interpretasi siswa mengenai keimanan itu tanpa merasa digurui karena model reflektif itu mendorong proses secara partisipatory. Pendidikan demokratis memungkinkan siswa merasa dihargai karena terdapat ruang yang cukup untuk menyampaikan pendapat serta memperoleh penghargaan.

Proses belajar mengajar Pendidikan Agama dalam kultur sekolah demokratis berpotensi membumikan deradikalisasi agama di sekolah karena peserta 
didik lebih cenderung mengoptimalkan kebebasan berpikir kritis, sikap kemandirian dan akuntabilitas untuk mendalami dan meyakini ajaran agamanya sendiri. Dengan pola pikir yang demokratis juga peserta didik dapat berkomitmen mentransformasikan dan mengaktualisasikan nilai-nilai ajaran agama menjadi nilai-nilai normatif yang mengatur tatanan hidup diri sendiri sekaligus menyikapi gerakan radikalisme.[w] 


\section{BIBLIOGRAFI}

Dewey, J., "Famous Declaration Concerning Education", pertama kali dipublikasikan di The School Journal, (versi electric), Vol. LIV, No. 3, 1987

Dewantara, KH., Pendidikan, Yogyakarta: Majelis Luhur Persatuan Taman Peserta didik, 1977.

Edwards, H.P., Religius Education in a Pluralist Society. London-Portland: Wobum, 1999.

Feertz. C., The Interpretation of Cultures. New York: Basic Books, 1973.

Gutmann, A., Democratic Education with a New Preface and Epilogue. New Jerset: Princeton University Press, 2006.

Hall. E.T, Beyond culture. New York: Anchor Books/Doubleday, 1976.

Nyamekye S.A., Religious Education in a Democratic State: The Case of Ghana. Departement of Religion \& Human Values, 2010.

Pamuji M, Nanang, dkk., "Success Story Mekanisme Komunitas dalam Penanganan dan Pencegahan Konflik: Studi Kasus di Desa Wayame (Ambon) dan Desa Tangkura (Poso)", Laporan Penelitian bersama Institut Titian Perdamaian, Friedrich Ebert Stiftung dan Panitia 40 tahun FES di Indonesia, 2008.

Wahid, Fathurrohman, "Pembelajaran Demokratis pada Bidang Studi Pendidikan Agama Islam di SMAN 29 Jakarta”, Skripsi, UIN Syarif Hidayatullah, Jakarta ,2010.

Zamroni, Pendidikan Demokrasi pada Masyarakat Cultural, Yogyakarta: Gavin Kalam Utama, 2003.

\section{Internet:}

Iga Lombok, "Fenomena Gerakan Radikalisme-Fundamental”, https:// jurnalsrigunting.wordpress.com/tag/radikalisme-terorisme-dankejahatan-cyber, diakses pada 21 Maret 2015.

Kamus Besar Bahasa Indonesia, Kamus versi online, http://kbbi.web.id/ radikalisme, diakses pada tanggal 18 Maret 2015.

"Konflik Antar Agama \& Etnis di Poso \& Sampit", http://www.museum. polri.go.id/lantai2_gakkum_konflik-poso-sampithtml 